\title{
ANALISIS HUKUM PEMBERIAN REMISI TERHADAP NARAPIDANA DI LEMBAGA PEMASYARAKATAN KLAS II A BINJAI
}

\author{
Heru Prabowo Adi Sastro \\ Kementerian Hukum dan HAM \\ Heru2653@gmail.com
}

\begin{abstract}
A B S T R A K
Pemberian remisi kepada narapidana merupakan perintah dari Undang-undang sebagai rangsangan agar narapidana bersedia menjalani pembinaan untuk merubah perilaku sesuai dengan tujuan Sistem Pemasyarakatan.Namun dalam pengawasannya yang melibatkan lembaga atau instansi di luar daripada Lembaga Pemasyarakatan tidak disertai dengan adanya suatu peraturan yang tegas dalam pelaksanaannya.Hal ini mengakibatkan adanya hambatan-hambatan yang justru mempersulit pemberian remisi kepadanarapidana.Penelitian dilakukan untuk mengetahui Pengawasan Pemberian Remisi Terhadap Narapidana di Lembaga Pemasyarakatan Klas II A Binjai.Adapun sifat penelitian adalah yuridis normatif. Bahan kepustakaan dan studi dokumen dijadikan sebagai bahan utama sementara data lapangan akan dijadikan sebagai data pendukung atau pelengkap. Data yang terkumpul dipilah dan dianalisis secara yuridis dan terhadap data yang sifatnya kualitatif ditafsirkan secara logis sistematis dengan metode deduktif dan induktif.Hasil penelitian menunjukkan bahwa pelaksanaan pemberian remisi kepada narapidana mengalami pergeseran baik dari pengertian, kriteria maupun tujuannya.Menurut ketentuan, remisi aslinya adalah hak narapidana, bergeser menjadi semacam hadiah yang diberikan oleh pemerintah, dan terakhir bergeser menjadi ajang/arena jual beli kepentingan.Akibat pergeseran tersebut, terjadi pengaburan terhadap aturan-aturan hukum pemberian remisi yang secara otomatis berdampak pada pengawasannya.Selain itu, pelaksanaan pemberian remisi merupakan suatu hak narapidana dan juga sebagai rangsangan agar narapidana bersedia menjalani pembinaan untuk merubah perilaku sesuai dengan tujuan Sistem Pemasyarakatan. Sistem pengawasan pemberian remisi di Lembaga Pemasyarakatan melibatkan Lembaga Pemasyarakatan yang dilakukan mulai dari Unit Pelaksana Teknis Pemasyarakatan, Kantor Wilayah Kementerian Hukum dan HAM untuk diteruskan kepada Direktorat Jenderal Pemasyarakatan, juga melibatkan Hakim Pengawas dan Pengamat. Hambatan yang dihadapi dalam pemberian remisi adalah belum adanya sarana peraturan perundang-undangan dan peraturan pelaksanaan sebagai payung hukum yang kuat yang merupakan landasan yuridis dan strukturil sebagai penunjang atau dasar bagi ketentuanketentuan operasionil suatu pengawasan pemberian remisi yang berlaku bagi semua pihak yang terlibat dalam pengawasan pemberian remisi, disamping adanya tindakan indisipliner dari narapidana, sehingga diupayakan untuk melaksanakan semaksimal mungkin peraturan perundang- undangan dan peraturan pelaksanaan ketentuan operasionil suatu pengawasan pemberian remisi khususnya yang terdapat di dalam Undang-Undang Pemasyarakatan.
\end{abstract}

\section{Kata Kunci : Pengawasan, Remisi, Narapidana, Lembaga Pemasyarakatan}

\begin{abstract}
ABSTRACK
The administration of remission to prisoner is order of the law as a stimulation so that prisioner are ready to receive the counseling to change the behavior according to goal of community system. But in controlling involving the institution or instances outside of the community system is not combined with a firm regulation in the implementation. This case causes there is the problem to make the administration of remission difficult for prisoner.The research is done to know the supervision of remission administration on prisoner in Prison related with the goal of community system. The nature of this research is normative yuridic. The materials of library and study of documents are made as main material of field data will
\end{abstract}


be made as supportive and completing data. The data gathered will be singled out and analyzed yuridically and to data of qualitative nature will be interpreted systematic logically.The result of the study shows that the implementation of the giving of remission upon the convicts deviates from time to time. The deviation includes its definition, criteria or objectives as well. In accordance with laws, originally, remission is the convict's rights now is likely a gift given the government and finally becomes an arena of transaction of people's interests. In results, there is an uncertainty of the regulations of the giving of remission which automatically influences to its monitoring. Beside it, implementation of remission administration is a right of prisoner and also as stimulation so that prisoner are ready to receive the counseling to change the behavior according o the goal of Community System. The controlling system in remission administration in Prison involves the Prison done beginning from Unit of Technique Impelemtor of Community, Regional fice Ministry of Law and Human Rights to be continued to Directorate General of Community, also involves the Controlling Judge and observer. The problem found in administration of remission is there is not yet the facility of statutes regulation and rule of implementation as law umbrella to be supporting of base for operational requirements for controlling the remission yuridical and structural foundation as supporting of base for iperational requirements for controlling the remission administration for all parties involved in the remission administration, beside there is indiciplinary action of prisoner, so that it is attempted to implement as maximum as possible the statutes and operational implementation rule of remission administration especially found in the law of Community.

\section{Key Word : Supervission, Remission, Prisoner, Prison}

\section{Pendahuluan}

Sistem Peradilan Pidana merupakan suatu sistem yang "masukan" (input) berupa pelaku-pelaku yang melakukan perbuatan melanggar hukum pidana untuk "diproses" dan selanjutnya menjadi "keluaran" (out put) kembali pada masyarakat seperti sediakala. Dengan demikian cakupan tugas sistem ini memang luas meliputi : (a) mencegah masyarakat menjadi korban kejahatan; (b) menyelesaikan kejahatan yang terjadi, sehingga masyarakat puas bahwa keadilan telah ditegakkan dan yang bersalah dipidana; serta (c) berusaha agar mereka yang pernah melakukan kejahatan tidak mengulangi lagi perbuatannya. Komponen-komponen yang bekerja sama dalam sistem ini terutama instansi-instansi (badan-badan) yang kita kenal dengan nama : kepolisian-kejaksaanpengadilan-dan pemasyarakatan. ${ }^{1}$

Sebagaimana diketahui bahwa Sistem Pemasyarakatan yang berlaku dewasa ini, secara konseptual dan historis sangat berbeda dengan apa yang berlaku dalam

\footnotetext{
${ }^{1}$ Mardjono Reksodiputro, Kriminologi dan SPP Kumpulan karangan Buku Kedua, cet.I, 2007, (Jakarta: Pusat Pelayanan keadilan dan Pengabdian Hukum UI), 2007, hal. 140.
}

Sistem Kepenjaraan. Asas yang dianut Sistem Pemasyarakatan menempatkan narapidana sebagai subyek yang dipandang sebagai pribadi dan warga negara biasa serta dihadapi bukan dengan latar belakang pembalasan tetapi dengan pembinaan dan bimbingan. Perbedaan dua sistem tersebut memberi implikasi perbedaan dalam caracara pembinaan dan bimbingan yang dilakukan, disebabkan perbedaan tujuan yang ingin dicapai.

Gerakan-gerakan pembaharuan Sistem Penjara terus berkembang, sebagai akibat dari gerakan kemanusiaan yang menganggap narapidana sebagai manusia yang utuh dan harus disosialisasikan serta ditunjang pula oleh penemuan-penemuan ilmiah baik ilmu sosial maupun ilmu alam yang bersifat empiris. ${ }^{2}$

Tujuan penghukuman adalah mencegah seseorang melakukan kejahatan dan bukan merupakan pembalasan dendam dari masyarakat. Usaha-usaha yang sama yang telah dilakukan dalam bidang kepenjaraan di negara Barat, khususnya di Amerika juga telah dilaksanakan di

2Muladi, Lembaga Pidana Bersyarat, (Bandung: Alumni), 1992, hal. 97. 
Indonesia sejak tahun 1964, sehingga muncul Sistem Kepenjaraan baru yang dikenal dengan Sistem Pemasyarakatan. ${ }^{3}$

PenyelenggaraanSistemPemasyaraka tanmempunyai inti tugas tentang pembinaan terhadap narapidana seperti dalam Piagam Pemasyarakatan sebagai hasil konferensi kerja Direktorat Pemasyarakatan pada tanggal 27 April sampai dengan 09 Mei 1964 di Bandung. Menurut pasal 1, 2 dan 6 Piagam Pemasyarakatan, arti tugas pembinaan adalah sebagai berikut :4

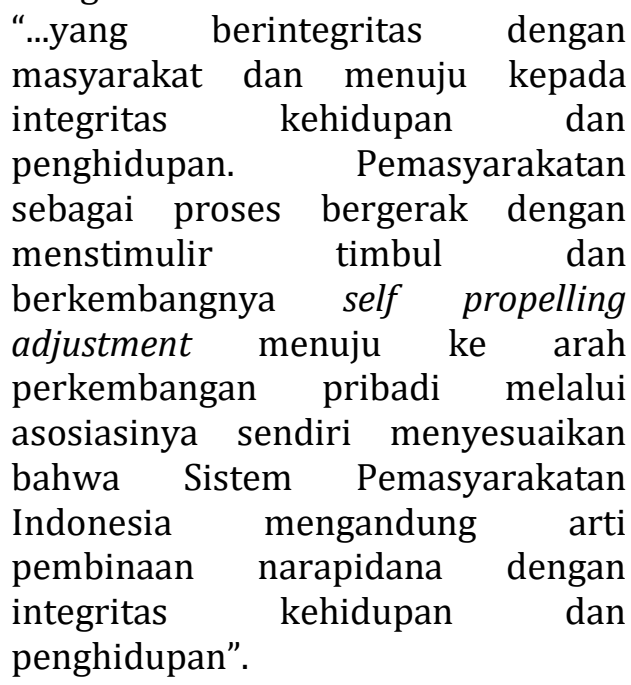

Pemasyarakatan adalah suatu proses therapeutic di mana si narapidana pada waktu masuk Lapas dalam keadaan tidak harmonis dengan masyarakat sekitarnya, dan mempunyai hubungan yang negatif dengan masyarakat. Sejauh itu narapidana lalu mengalami pembinaan yang tidak lepas dari unsur-unsur lain dalam masyarakat, sehingga pada akhirnya narapidana dengan masyarakat sekelilingnya merupakan suatu keutuhan dan keserasian (keharmonisan) hidup dengan penghidupan, tersembuhkan dari segi-segi yang merugikan (negatif). ${ }^{5}$

Tujuan penyelenggaraan Sistem Pemasyarakatan merupakan pembentukan warga binaan menjadi manusia seutuhnya, menyadari kesalahan, memperbaiki diri,

${ }^{3}$ Romli Atmasasmita, Dari Pemenjaraan Ke Pembinaan Narapidana, (Bandung: Alumni), 1975, hal 72.

4Bambang Poernomo, PelaksanaanPidanaPenjaraDenganSistemPemasya rakatan, (Yogyakarta: Liberty), 1986, hal 186.

${ }^{5}$ Andi Hamzah, Suatu Tinjauan Ringkas Sistem Pemidanaan di Indonesia, (Jakarta: Akademika Pressindo), 1983, hal 116. tidak mengulangi tindak pidana, kembali ke masyarakat, aktif dalam pembangunan, hidup wajar sebagai warganegara dan bertanggungjawab. Sedangkan fungsi penyelenggaraan Sistem Pemasyarakatan adalah menjadikan warga binaan menyatu (integral) dengan sehat dalam masyarakat dan dapat berperan bebas serta bertanggungjawab. Maksud dari manusia seutuhnya ditafsirkan narapidana dan anak pidana sebagai sosok manusia yang diarahkan kefitrahnya untuk menjalin hubungan dengan Tuhan, pribadi serta lingkungan. Sedangkan tafsir terintegrasi secara sehat dijelaskan sebagai pemulihan hubungan warga binaan pemasyarakatan (WBP) dengan masyarakat. ${ }^{6}$

Remisi atau pengurangan penghukuman selama narapidana menjalani hukuman pidana juga berubah dari waktu ke waktu.Sistem Kepenjaraan menempatkan remisi sebagai hadiah.Artinya remisi adalah hadiah dari Pemerintah kepada narapidana.Sejak tahun 1950, remisi tidak lagi sebagai anugerah, tetapi menjadi hak setiap narapidana yang memenuhi syarat yang ditetapkan.

Dalam sistem baru pembinaan narapidana, remisi ditempatkan sebagai motivasi (salah satu motivasi) bagi narapidana untuk membina diri sendiri. Sebab, remisi tidak sebagai hukum seperti dalam Sistem Pemasyarakatan, tidak pula sebagai anugerah sebagaimana dalam sistem kepenjaraan, tetapi sebagai hak dan kewajiban narapidana. Artinya jika narapidana benar-benar melaksanakan kewajibannya, ia berhak untuk mendapat remisi, sepanjang persyaratannya telah dipenuhi. $^{7}$

\section{Perumusan Masalah}

1. Bagaimana aturan hukum hak narapidana tentang remisi dalam Sistem Peradilan Pidana di Indonesia ?

6Permen Hukum dan Hak Asasi Manusia Republik Indonesia No, M.HH-OT.02.02 Tahun 2009 tentang Cetak Biru Pembaharuan Pelaksanaan Sistem Pemasyarakatan, hal. 123.

${ }^{7} \mathrm{CI}$. Harsono, Sistem Baru Pembinaan Narapidana, (Jakarta: Djambatan), 1995, hal. 25. 
2. Bagaimana pelaksanaan pemberian remisi kepada narapidana di Lembaga Pemasyarakatan Klas II A Binjai?

3. Apa hambatan dan upaya dalam pelaksanaan pemberian remisi kepada narapidana di Lembaga Pemasyarakatan Klas II A Binjai ?

\section{Tujuan Penelitian}

Berdasarkan rumusan masalah yang telah dikemukakan diatas, maka penelitian ini bertujuan :

1. Untuk mengetahui aturan hukum hak narapidana tentang remisi dalam Sistem Peradilan Pidana di Indonesia.

2. Untuk mengetahui pelaksanaan pengawasan pemberian remisi kepada narapidana di Lembaga Pemasyarakatan Klas II A Binjai.

3. Untuk mengetahui hambatan dan upaya dalam pelaksanaan pemberian remisi kepada narapidana di Lembaga Pemasyarakatan Klas II A Binjai.

\section{Metode Penelitian}

A. Waktu Penelitian

Waktu penelitian direncanakan pada Bulan Juli 2016 sampai dengan Bulan Agustus 2016

\section{B. Sifat dan Jenis Penelitian}

Untuk mengumpulkan data dalam usulan penelitian ini dilakukan dengan penelitian yang bersifat deskriptif analitis, yaitu penelitian yang tidak hanya menggambarkan permasalahan saja, tetapi peraturan dalam hal pemberian remisi dan pelaksanaannya dalam praktek. Pengumpulan data dengan cara deskriptif ini adalah metode pendekatan yang dilakukan melalui pendekatan secara yuridis normatif, yaitu mengkaji dan menelaah aspek hukum mengacu pada norma-norma hukum yang terdapat dalam peraturan perundangundangan, khususnya hukum pidana yang berkaitan dengan remisi.

\section{Data dan Sumber Data}

Dalam penelitian pada umumnya dibedakan antara data yang diperoleh secara langsung dari masyarakat dan dari bahan-bahan pustaka. Yang diperoleh langsung dari masyarakat dinamakan data primer (atau dasar), sedangkan yang diperoleh dari bahan-bahan pustaka lazimnya dinamakan data sekunder. ${ }^{8}$ Sumber data dalam penelitian ini terdiri dari:

1. Bahan Hukum Primer, antara lain:

a. Norma atau kaedah dasar.

b. Peraturan dasar.

c. Peraturan Perundang-undangan yang berkaitan dengan Sistem Pemasyarakatan dan peraturan pemberian remisi antara lain, Undang-Undang Nomor 12 Tahun 1995 tentang Pemasyarakat-an, Kitab Undang-Undang Hukum Pidana (KUHP), Kitab Undang-Undang Hukum Acara Pidana (KUHAP), Keputusan Presiden Nomor 174 Tahun 1999 Tentang Remisi, Keputusan Menteri Nomor M.02.PK.04.10 Tahun 1990 dan lainlain yang mengatur tentang remisi.

\section{Bahan Hukum Sekunder}

Untuk menghimpun data sekunder, maka dibutuhkan bahan berupa buku yang berkaitan dengan Sistem Pemasyarakatan baik tentang Pembinaan maupun pengawasan, karya ilmiah dan hasil-hasil seminar yang relevan dengan penelitian ini serta pendapat ahli yang dilengkapi dengan data primer.

3. Bahan Hukum Tersier

Bahan hukum penunjang yang mencakup bahan yang memberi petunjukpetunjuk dan penjelasan terhadap bahan hukum primer, sekunder seperti kamus umum, kamus hukum, majalah dan jurnal ilmiah, serta bahan-bahan di luar bidang hukum yang relevan dan dapat dipergunakan untuk melengkapi data yang diperlukan dalam penelitian. ${ }^{9}$

\section{MetodePendekatan}

Metode pendekatan yang dilakukan adalah pendekatan yuridis normatif, yaitu

8Soerjono Soekanto dan Sri Mamudji, Penelitian Hukum Normatif suatu Tinjauan Singkat, (Jakarta: Rajawali Pers), 1983, hal. 12.

${ }^{9}$ Bambang Sunggono, Metodologi Penelitian Hukum, (Jakarta: Ghalia Indonesia 1998), hal.195, sebagaimana dikutip dari Soerjono Soekanto dan Sri Mamuji, Penelitian Hukum NormatifSuatu Tinjauan Singkat, (Jakarta Rajawali Press, 1990), hal. 41 
mengkaji dan menelaah aspek hukum mengacu pada norma-norma hukum yang terdapat dalam peraturan perundangundangan, khususnya hukum pidana yang berkaitan dengan remisi.

\section{E. Alat Pengumpul Data}

Teknik pengumpulan data dilakukan dengan menggunakan teknik observasi dan studi dokumen. Teknik observasi diartikan sebagai gejala yang tampak atau pencatatan objek penelitian untuk melihat dan mengamati secara langsung di lapangan tentang keberadaan (situasi dan kondisi) Lapas Klas IIA Binjai dengan tujuan untuk memperoleh data yang akurat terkait dengan objek penelitian. Sedangkan studi dokumen digunakan untuk mengumpulkan bahan-bahan hukum berupa Peraturan Perundang-undangan dan peraturan lainnya yang terkait dengan pokok permasalahan dan pertanyaan penelitian dalam tesis ini.

\section{F. Analisis Data}

Data yang diperoleh dari hasil penelitian kemudian disajikan dengan pendekatan kualitatif. Pada tahap awal dilakukan pengumpulan data primer dan sekunder, kemudian data dikelompokkan sesuai dengan rumusan masalah yang ditetapkan. Data-data tersebut selanjutnya dikelompokkan untuk mendapat gambaran yang utuh, menyeluruh dan tepat sebagai pemecahan masalah-masalah yang akan dijawab. Berikutnya dilakukan penulisan hasil penelitian dengan metode deskriptif analitis di mana seluruh fakta dan permasalahan yang berhubungan dengan objek penelitian akan disajikan secara utuh, setelah dianalisis berdasarkan norma norma hukum yang dituangkan dalam Peraturan Perundang-undangan. ${ }^{10}$

\section{Hasil dan Pembahasan}

\section{A. Aturan Hukum Hak Narapidana tentang Remisi dalam Sistem Peradilan Pidana}

Dalam KUHP yang berlaku sekarang di Indonesia, pengaturan sanksi menerapkan sistem dua jalur (double track system).

${ }^{10}$ Soerjono Soekamto, Pengantar Penelitian Hukum, Cetakan Ketiga, (Jakarta : UU Press 1996), hal. 10.
Sistem demikian tetap dipertahankan dalam pembaharuan hukum pidana nasional, sebagaimana dirumuskan dalam Rancangan KUHP (Baru) Tahun 2008. Jenis-jenis pidana dirumuskan sebagai berikut: ${ }^{11}$

1. Pidana pokok terdiri atas :
a. Pidana penjara ;
b. Pidana tutupan;
c. Pidana pengawasan;
d. Pidana denda;
e. Pidana kerja sosial.

2. Urutan pidana pokok di atas menentukan berat ringannya pidana.

3. Pidana mati merupakan pidana yang bersifat khusus dan selalu diancamkan secara alternatif.

4. Pidana tambahan terdiri atas :
a. Pencabutan hak tertentu;
b. Perampasan barang-barang tertentu dan/atau tagihan;
c. Pengumuman putusan hakim;
d. Pembayaran ganti rugi; dan
e. Pemenuhan kewajiban adat setempat dan/atau kewajiban menurut hukum yang hidup dalam masyarakat.
Sedangkan jenis-jenis tindakan diatur dalam Pasal 101 Rancangan KUHP (Baru) Tahun 2008 sebagai berikut: ${ }^{12}$

1. Hakim dalam pelaksanaannya dapat menjatuhkan tindakan kepada mereka yang memenuhi Pasal 40 dan Pasal 41 berupa :
a. Perawatan di Rumah Sakit Jiwa;
b. Penyerahan kepada pemerintah;
c. Penyerahan kepada seseorang.

2. Hakim dalam putusannya dapat menjatuhkan tindakan bersama-sama dengan pidana pokok berupa :
a. Pencabutan izin mengemudi;
b. Perampasan keuntungan yang diperoleh dari tindak pidana;
c. Perbaikan akibat-akibat tindak pidana;
d. Latihan kerja:
e. Perawatan di dalam suatu lembaga. Rancangan KUHP yang telah beberapa kali diubah dan diperbaharui (yang sampai sekarang hanya sebatas rancangan

11Petrus Irwan Pandjaitan dan Samuel Kikilaitety, Pidana Penjara Mau Kemana, (Jakarta:Ind Hill Co, cet. Pertama, 2007), hal. 5.

${ }^{12}$ Ibid, hal. 6. 
atau keinginan sebagian orang yang peduli terhadap perubahan dan kemajuan dunia hukum) sebenarnya telah cukup untuk menggambarkan bahwa ada ketertinggalan cara pandang atau paradigma yang sudah tidak sesuai dengan situasi dan kondisi saat ini khususnya di Indonesia terkait dengan pidana dan pemidanaan. Dari Rancangan KUHP itu sudah sangat jelas tergambar keinginan dari para perancangnya supaya tidak lagi memandang pidana dan pemidanaan sebagai bentuk "pembunuhan terhadap karakter manusia yang melanggarnya" tetapi lebih melihat sanksi pidana sebagai bentuk "obat/pengobatan terhadap manusia yang sedang sakit". ${ }^{13}$

Rancangan KUHP (Baru) Tahun 2008 bahkan telah memasukkan pemenuhan kewajiban adat setempat dan/atau kewajiban menurut hukum yang hidup dalam masyarakat sebagai bentuk hukuman tambahan yang dianggap bias membantu mempercepat proses pemulihan baik untuk si pelaku maupun untuk masyarakat yang terganggu keadaannya akibat perbuatan atau ulah si pelaku/pelanggar. ${ }^{14}$

Remisi merupakan salah satu bagian dari fasilitas pembinaan yang tidak bisa dipisahkan dari fasilitas pembinaan yang lainnya, di mana hakekat pembinaan adalah selain memberikan sanksi yang bersifat punitif, juga memberikan reward sebagai salah satu upaya pembinaan, agar program pembinaan dapat berjalan dan direspon oleh WBP, sedangkan tujuan dari Sistem Pemasyarakatan adalah mengupayakan warga binaan untuk tidak mengulangi lagi perbuatannya melanggar hukum yang pernah dilakukan sebagai warga masyarakat serta dapat berperan aktif sebagaimana anggota masyarakat lainnya. ${ }^{15}$

Pemberian remisi tidak dianggap sebagai bentuk kemudahan-kemudahan bagi WBP untuk cepat bebas, tetapi agar dijadikan sarana untuk meningkatkan kualitas diri sekaligus memotivasi diri, sehingga dapat mendorong WBP kembali memilih jalan kebenaran. Kesadaran untuk menerima

\footnotetext{
${ }^{13}$ Ibid, hal. 9.

${ }^{14}$ Ibid

${ }^{15}$ Dwidja Priyatno, Sistem Pelaksanaan
} Pidana Penjara di Indonesia, cet. pertama (Bandung Refika Aditama), 2006, hal. 106. dengan baik pembinaan yang dilakukan oleh Lapas maupun Rutan akan berpengaruh terhadap kelangsungan kehidupan di masa mendatang. Perlu kita sadari bahwa manusia mempunyai dua potensi dalam kehidupannya, yaitu potensi untuk berbuat baik dan potensi untuk melakukan perbuatan buruk (jahat), sehingga siapapun dapat berbuat salah atau khilaf. Namun dengan tekad dan kesungguhan hati untuk memperbaiki diri, niscaya masyarakat akan memberikan apresiasi dan kepercayaan kepada WBP untuk berada kembali di tengah-tengah masyarakat. Pemberian remisi dimaksudkan juga untuk mengurangi dampak negatif dari sub-kultur tempat pelaksanaan pidana, disparitas pidana dan akibat pidana perampasan kemerdekaan. ${ }^{16}$

Secara psikologis pemberian remisi mempunyai pengaruh dalam menekan tingkat frustasi sehingga dapat mereduksi atau meminimalisasi gangguan keamanan dan ketertiban di Lapas, Rutan dan cabang Rutan, berupa pelarian, perkelahian dan kerusuhan lainnya. ${ }^{17}$

Pemberian remisi hendaknya dapat dijadikan semangat dan tekad bagi warga binaan untuk mengisi hari-hari menjelang bebas dengan memperbanyak karya dan cipta yang bermanfaat bagi sesama. Sehingga upaya WBP untuk mendapatkan remisi tersebut dapat dimaknai sebagai persiapan diri dan kesungguhan untuk tidak melanggar hukum lagi yang akan sangat mendukung dan menunjang keberhasilan warga binaan pemasyarakatan dalam berintegrasi dengan masyarakat tempat di mana warga binaan pemasyarakatan kembali. ${ }^{18}$

Dari beberapa penjelasan tersebut di atas, dapat diambil kesimpulan bahwa pengertian remisi diartikan sebagai pengurangan hukuman terhadap narapidana dan anak pidana yang berkelakuan baik dengan tujuan untuk memotivasi narapidana yang bersangkutan dan narapidana yang lain untuk berbuat baik dan segera menjalani

${ }^{16}$ Menteri Hukum dan HAM, Sambutan Menteri Hukum dan Ham RI Pada upacara PemberianRemisi Kepada WBP Pada Upacara Memperingati Hari Ulang Tahun Proklamsi Kemerdekaan RI Ke 63, Jakarta, 17 Agustus 2008.

${ }^{17}$ Ibid.

${ }^{18}$ Ibid. 
kehidupan di masyarakat. Remisi bisa dijadikan sebagai sarana untuk memotivasi narapidana melaksanakan program-program yang ada di Lapas supaya dijalankan dengan baik, melaksanakan peraturan tata tertib dengan harapan yang bersangkutan mendapatkan pengurangan hukuman sehingga bisa segera kembali menjalani kehidupan di masyarakat secara normal.

Bagi narapidana kebanyakan, hak remisi merupakan hak yang diharapkan dan ditunggu-tunggu sehingga dengan berkurangnya hukuman segera dapat menghirup udara bebas. Namun demikian hak itu juga dapat menimbulkan kecemburuan dikalangan mereka. Hal ini dapat terjadi karena dalam pelaksanaannya tidak terlepas dari faktor subyektifitas pihak penilai di samping faktor-faktor lain yang berperan (ekonomi). Sebagai contoh, untuk mendapatkan Remisi Tambahan salah satu syaratnya adalah "melakukan perbuatan yang membantu kegiatan pembinaan di Lapas". Untuk syarat ini yang berpeluang lebih besar dapat melakukannya adalah narapidana yang mempunyai dana yang besar, sedangkan narapidana yang tidak mampu secara ekonomi tidak dapat melaksanakan program tersebut.

Dalam rangka pelaksanaan pemberian remisi khususnya remisi tambahan, agar tidak menimbulkan kecemburuan di kalangan narapidana dan kecurigaan masyarakat, perlu adanya optimalisasi lembaga pengawasan mulai dari Unit Pelaksana Teknis (UPT) Pemasyarakatan setempat yang juga melibatkan Hakim Wasmat dengan menitikberatkan pengawasannya pada hakhak narapidana sudah sesuai dengan ketentuan yang ada.

Didalam Undang - Undang No. 12 Tahun 1995 tentang Pemasyarakatan dalam Pasal 14 bahwa narapidana berhakmendapatkan: ${ }^{19}$

a. melakukan ibadah sesuai dengan agama ataukepercayaannya,

b. mendapat perawatan, baik perawatan rohani maupunjasmani,

c. mendapatkan

pendidikan danpengajaran,

${ }^{19}$ Pasal 14 Undang-undang Nomor 12 Tahun 1995 tentang Pemasyarakatan. d. mendapatkan pelayanan kesehatan dan makanan yanglayak,

e. menyampaikankeluhan,

f. mendapatkan bahan bacaan dan mengikuti siaran media massa lainnya yang tidak dilarang,

g. mendapatkan upah atau pemi atas pekerjaan yangdilakukan,

h. menerima kunjungan keluarga, penasihat hukum, atau orang tertentulainnya,

i. mendapatkan pengurangan masa pidana(remisi),

j. mendapatkan kesempatan berasimilasi termasuk cuti mengunjungikeluarga,

k. mendapatkan pembebasanbersyarat,

l. mendapatkan cuti menjelang bebas,dan

m. mendapatkan hak-hak lain sesuai dengan peraturan perundang undangan yang berlaku.

Keputusan Presiden Nomor 174 Tahun 1999 Pasal 1 ayat (1) menyebutkan bahwa, "setiap Narapidana dan anak pidana yang menjalani pidana penjara sementara dan pidana kurungan dapat diberikan remisi apabila yang bersangkutan berkelakuan baik selama menjalani pidana".20 $\mathrm{Di}$ dalam Peraturan Pemerintah Republik Indonesia No. 32 Tahun 1999 Pasal 34 ayat (1) menyebutkan bahwa: "setiap Narapidana dan anak pidana yang selama menjalani masa pidana berkelakuan baik berhak mendapatkan remisi". ${ }^{21}$

Dalam Keputusan Presiden Nomor 174 Tahun 1999 tentang Remisi, menyatakan bahwa remisi merupakan salah satu tujuan sarana hukum yang penting dalam rangka mewujudkan Sistem Pemasyarakatan. Berkaitan dengan hal tersebut, posisi lembaga remisi adalah merupakan salah satu alat pembinaan dalam Sistem Pemasyarakatan yang berfungsi :

1. Sebagai katalisator (untuk mempercepat) upaya meminimalisasi pengaruh prisonisasi.

2. Sebagai katalisator (untuk mempercepat) proses pemberian Remisi.

${ }^{20}$ Keppres No. 174 Tahun 1999 tentang

21Peraturan Pemerintah No. 32 Tahun 1999 tentang Syarat dan tata acara hak WBP. 
tanggung jawab di dalam masyarakat luas.

3. Sebagai alat modifikasi perilaku dalam proses pembinaan selama di dalam Lapas.

4. Dalam rangka efisiensi anggaran Negara. Remisi adalah pengurangan hukuman dan merupakan hak yang dimiliki oleh setiap narapidana. Tentunya hak tersebut diberikan kepada mereka yang memenuhi syarat untuk mendapatkan remisi dimaksud. Syarat tersebut adalah berkelakuan baik, tidak dikenakan hukuman disiplin, sudah menjalani pidana lebih dari 6 (enam) bulan, tidak dijatuhi hukuman mati/seumur hidup dan tidak sedang menjalani pidana pengganti denda dan tidak sedang menjalani cuti menjelang bebas (CMB).

Pemberian Remisi bukanlah merupakan wujud belas kasihan Pemerintah kepada warga Negara Binaan. Remisi adalah refleksi dan tanggung jawab warga binaan terhadap dirinya sendiri, yaitu sebagai tanggung jawab atas pelanggaran yang telah dilakukan. Remisi adalah refleksi itikad baik warga binaan terhadap petugas. ${ }^{22}$

\section{B. Pelaksanaan Pengawasan Pemberian Remisi kepada Narapidana di Lembaga Pemasyarakatan Klas II A Binjai}

Lembaga Pemasyarakatan Klas II A Binjai adalah Unit Pelaksana Teknis (UPT) di bidang Pemasyarakatan yang berada di bawah dan bertanggung jawab langsung kepada Kantor Wilayah Kementerian Hukum Dan HAM Sumatera Utara.

Sebagai salah satu UPT Pemasyarakatan maka Lembaga Pemasyarakatan Klas II A Binjai mempunyai fungsi berdasarkan Keputusan Menteri Kehakiman RI Nomor M.05.PR.07.03 Tahun 2003 tentang Struktur Organisasi dan Tata Kerja Lembaga Pemasyarakatan dan UU Nomor 12 Tahun 1995 Lembaga Pemasyarakatan : mempersiapkan Warga Binaan Pemasyarakatan agar dapat berintegrasi secara sehat dengan masyarakat sehingga dapat berperan

${ }^{22}$ Majalah Hukum Dan HAM Vol. IV No. 20 September-Oktober 2006, hal. 11. kembali sebagai anggota masyarakat yang bebas dan bertanggung jawab,untuk menyelenggarakan fungsi tersebut Lembaga Pemasyarakatan Klas II A Binjai melaksanakan tugas sebagai berikut:

1. Melaksanakan Pembinaan Narapidana/Anak Didik Di Lembaga Pemasyarakatan.

2. Memberikan bimbingan, perawatan, terapi terhadap Narapidana/Anak Didik di Lembaga Pemasyarakatan Klas II A Binjai.

3. Melakukan bimbingan kerohanian/social.

4. Melakukan keamanan dan tata tertib Lembaga Pemasyarakatan.

5. Melakukan urusan tata usaha dan rumah tangga.

Sistem pembinaan yang dilaksanakan di Lembaga Pemasyarakatan Klas II A Binjai berdasarkan pada Surat Edaran Nomor : KP.10.13/3/1 tanggal 08 Februari 1965 tentang SistemPembinaan.

Selain itu tugas Lembaga Pemasyarakatan tercantum dalam Undangundang Nomor : 12 Tahun 1995 Bab I Ketentuan Umum Pasal 2 bahwa Sistem Pemasyarakatan diselenggarakan dalam rangka membentuk warga binaan pemasyarakatan agar menjadi manusia seutuhnya, menyadari kesalahan, memperbaiki diri dan tidak melanggar tindak pidana sehingga dapat diterima kembali oleh lingkungan masyarakat dapat aktif berperan dalam pembangunan dan hidup wajar sebagai warga yang baik dan bertanggung jawab.

Pohon Beringin Pengayoman dalam kaitannya dengan narapidana dan anak didik, adalah merupakan suatu gagasan, ide, atau konsepsi tentang tujuan pidana penjara dan pelaksanaannya yaitu pelaksanaan pidana penjara yang disebut "Pemasyarakatan".

Terhadap gagasan yang dicetuskan oleh Sahardjo tersebut sebagai manusia Indonesia tidak terkecuali harus mengangkat topi yang setinggi-tinginya atas gagasan yang telah dikemukannya itu, demikian juga Negara Indonesia c.q. Pemerintah Indonesia sudah sepantasnyalah memberikan penghargaan yang juga setinggi- tingginya atas jasa-jasa beliau untuk memperjuangkan "hak asasi manusia" bagi semua khususnya 
bagi narapidana yang semula dianggap sebagai sampah masyarakat karena telah tersesat jalan hidupnya. Memang demikianlah seharusnya."Negara yang besar adalah Negara yang tahu bagaimana memperlakukan dan membina para membina para pelanggar hukumnya". ${ }^{23}$

Hingga saat ini masih banyak terdapat perselisihan paham dan keraguraguan tentang apa yang dimaksud dengan Pemasyarakatan, dan akibatnya nampak sekali dalam pelaksanaan-pelaksanaannya. Sebagian pelaksana dalam gerak usahanya mengindentikkan Pemasyarakatan itu dengan pemberian kelonggaran-kelonggaran yang lebih banyak kepada para narapidana, dengan jalan membiarkan mereka keluyuran diluar tembok, sebagian pelaksanaan mewujudkan pemasyarakatan itu sebagai fase behandeling (perlakuan) terakhir, sebagai overgangs fase dari dalam tembok ke tengah-tengah masyarakat, sebagian lagi menyamakan Pemasyarakatan itu dengan sosialisasi. ${ }^{24}$

Kalau gerak usaha menurut konsepsi liberal terutama berpusat kepada individu (narapidana) yang bersangkutan dan ditujukan pula kepada individu yang bersangkutan, maka gerak usaha menurut konsepsi Pemasyarakatan berpusat dan ditujukan kepada integritas kehidupan dan penghidupan dimana individu (narapidana) adalah salah satu dari anggotanya (elemennya).

Kedudukan dari Pemasyarakatan dalam hal ini adalah sebagai sebagian dari pengejawatahan keadilan (administration of justice) dan lebih khusus lagi dalam bidang tata urusan perlakuan dari mereka yang karena mengingkari tata tertib masyarakat dengan keputusan Hakim ditempatkan di bawah pengawasan atau perawatan/asuhan Pemerintah.

\section{Hambatan dan Upaya dalam Pelaksanaan Pemberian Remisi kepada Narapidana di Lembaga Pemasyarakatan Klas II A Binjai}

${ }^{23}$ A. Widiada Gunakarya.S.A, Sejarah Dan Konsepsi Pemasyarakatan,(Bandung; Armico), 1988, hal. 62-63.

${ }^{24}$ Ibid, hal. 65
Berdasarkan hasil penelitian yang dilakukan secara langsung di Lembaga Pemasyarakatan Klas II A Binjai dalam pelaksanaan pemberian remisi terhadap Narapidana dan anak didik masih terdapat beberapa faktor yang menjadi penghambat, antara lain adalah :

1. FaktorYuridis

Dalam pelaksanaan pemberian remisi masih terdapat hal-hal yang menghambat secara yuridis dalam pelaksanaannya, hambatan tersebut yaitu belum adanya sarana peraturan perundangundangan dan peraturan pelaksanaan sebagai payung hukum yang kuat yang merupakan landasan yuridis dan strukturil sebagai penunjang atau dasar bagi ketentuan-ketentuan operasionil suatu pengawasan pemberian remisi, dalam hal ini peraturan perundang-undangan dan peraturan pelaksanaan yang berlaku bagi semua pihak yang terlibat dalam pengawasan pemberian remisi. Karena pengawasan pemberian remisi melibatkan beberapa instansi termasuk di luar Lembaga Pemasyarakatan atau Kementerian Hukum dan HAM sendiri, seperti Hakim Pengawas, Pengamat dan Jaksa yang secara tidak langsung terlibat karena seringnya terjadi keterlambatan pemberian/penyerahan eksekusi oleh pihak Kejaksaan yang mengakibatkan keterlambatan pengajuan remisi bagi narapidana.

2. Faktor Kelembagaan dan Sumber DayaManusia

Belum adanya suatu lembaga atau institusi yang khususmengawasi pemberian remisi kepada narapidana.Hal ini sangat diperlukan untuk meminimalisir terjadinya keterlambatan pemberian hak narapidana khususnya remisi dan menekan sekecil mungkin terjadinya kesalahan dalam pemberian remisi.Hal ini tentunya dibarengi dengan adanya syarat-syarat yang lebih spesifik dalam mendapatkan remisi.

Keterbatasan Sumber Daya Manusia yang dalam tugas pokok dan fungsinya yang berkompeten dalam pelaksanaan tugas tersebut, disamping itu juga ketiadaan sarana untuk penghitung remisi.Contoh keterbatasan sumber daya manusia pada pegawai Lembaga Pemasyarakatan Klas II A Binjai yang bertugas di bagian registrasi belum banyak mengikuti pelatihan dan 
pendidikan tentang perhitungan remisi, kemudian jumlah petugas dibagian tersebut sangat minim.Dilihat dari jumlah narapidana yang ada pada Lembaga Pemasyarakatan Klas II A Binjai pada saat ini lebih kurang 1100 orang.Seyogyanya minimal 10 (sepuluh) orang pegawai yang bertugas di bagian registrasi, kenyataannya pada saat sekarang hanya ada pegawai 6 (enam) orang termasuk Kepala Sub Seksi Registrasi ini merupakan suatu penghambat dala kelancaran pengusulan narapidana untuk mendapatkan remisi.

3. Faktor Sarana danPrasarana

Ketiadaan sarana untuk penghitung remisi, karena penghitungannya masih dilaksanakan secara manual yaitu dengan menggunakan alat telram yang juga digunakan untuk menghitung Ekspirasi (perhitungan bebas/ lepas narapidana).Ketiadaan sarana untuk perhitungan remisi masih memakai secara manual dengan memakai alat teleram, seharusnya perhitungan tersebut dilakukan dengan memakai alat yang canggih seperti komputerisasi.

4. Faktor dari PerilakuNarapidana

Salah satu faktor sebagai penghambat pemberian remisi adalah yang berasal dari diri narapidana sendiri dimana narapidana terlibat/melakukan tindakan indispliner atau hal-hal lain yang merupakan pelanggaran disiplin, sehingga narapidana masuk dalam catatan Register F,25sehingga hak untuk memperoleh remisi dicabut,seperti:

a Narapidana mencoba melarikan diri dari Lembaga Pemasyarakatan atau melarikan diri kemudian tertangkap kembali, maka usulan remisi yang bersangkutan menjadi penghambat untuk mendapatkanremisi.

b. Narapidana membuat atau terlibat keributan di dalam lembaga pemasyarakatan.

c. Narapidana tersebut melawan kepada petugaspemasyarakatan.

5. FaktorBudaya/Kultural

Kemudian juga masih terdapat juga faktor-faktor menghambat secara

${ }^{25}$ Register F (daftar warga binaan Pemasyarakatan yang melakukan pelanggaran tata tertib lapas budaya/kultural dalam pemberian remisi tersebut yaitu:

a. Adanya keterlambatan dalam hal persyaratan pengajuan remisi seperti ; petikan vonis dari Pengadilan Negeri yang memutus perkara narapidana tersebut hingga terkadang untuk untuk diusulkan mendapat remisi meskipun narapidana tersebut sudah lama diputus oleh pengadilan namun tidak dapatdiusulkan.

b. Adanya keterlambatan eksekusi dari kejaksaan negeri sehingga narapidana tersebut belum berkuatan hukum tetap dapat menghambat dalam usul pemberian remisi. Keterlambatan eksekusi dari kejaksaan menjadi faktor penghambat bagi narapidana untk diusulkan mendapat remisi, contohnya adalah narapidana tersebut sudah lama diputus oleh Hakim oleh Pengadilan Negeri, namun eksekusi dari Kejaksaan Negeri belum datang. Padahal pada saat itu narapidana itu sudah dapat diusulkan sudah mendaatkan remisi karena sudah menjelang 17 Agustus atau pada hari besar keagamaan sehingga narapidana tersebut terhambat untuk diusulkan untuk mendapatkanremisi.

Perlu adanya upaya penyempurnaan dengan melakukan langkah-langkah untuk meminimalisir terjadinya hambatan dalam pemberian remisi, antara lain;

1. FaktorYuridis

Melaksanakan semaksimal mungkin peraturan perundang-undangan dan peraturan pelaksanaan ketentuan operasionil suatu pengawasan pemberian remisi khususnya yang terdapat di dalam Undang - Undang Nomor 12 Tahun 1995 tentang Pemasyarakatan. Sambil menunggu adanya suatu peraturan perundangundangan dan peraturan pelaksanaan yang berlaku bagi semua pihak yang terlibat dalam pengawasan pemberian remisi. Karena pengawasan pemberian remisi melibatkan beberapa instansi termasuk di luar Lembaga Pemasyarakatan atau Kementerian Hukum dan HAM sendiri, seperti Hakim Pengawas dan Pengamat dan Jaksa atau pihak Kejaksaan yang secara tidak langsung terlibat dalam pengajuan remisi bagi narapidana. 
2. Faktor Kelembagaan dan Sumber DayaManusia

Memberdayakan setiap lembaga atau institusi yang terlibat dalam pengawasan pemberian remisi kepada narapidana, melalui menjalin hubungan baik dengan instansi terkait. Hal ini sangat diperlukan untuk meminimalisir terjadinya keterlambatan pemberian hak narapidana khususnya remisi dan menekan sekecil mungkin terjadinya kesalahan dalam pemberian remisi.Peningkatan Sumber Daya Manusia yang mampu dan berkompeten dalam bidang tugasnya, dimana pegawai harus mempunyai keahlian tentang Pemasyarakatan agar tercipta sesuatu kerjasama yang baik sehingga pelaksanaan tugas dapat berjalan sesuai dengan tujuan yang telah di tetapkan. Dalam rangka meningkatkan kualitas pegawai, maka khusus petugas di registrasi lebih sering diikutkan dalam berbagai pelatihan pemasyarakatan.

Sebagai pendukung diadakan penambahan petugas di bidang registrasi untuk dapat lebih cepat dalam pemberian usul remisi, mengingat penghuni di lapas pada saat ini sudah over kapasitas sehingga dalam proses pengusulan remisi sering dapat terlambat. Di sisi lain, diadakan sosialisasi kepada petugas khusus yang bertugas dibagian pembinaan (registrasi) dalam rangka meningkatkan pengetahuan tentang perhitungan dalam usulanremisi.

\section{Faktor Sarana danPrasarana}

Meningkatkan pengadaan sarana untuk perhitungan remisi dengan tidak lagi memakai secara manual tetapi dengan tehnologi yang canggih, dengan sarana komputerisasi khusus yang dapat di program untuk perhitungan remisi. Sehingga mempermudah pelaksanaan pemberian remisi, karena data-data dari narapidana sudah terperinci dengan baik dan hal ini akan mempermudah aplikasi penghitungan remisi untuk setiapnarapidana.

4. Faktor dari PerilakuNarapidana

Pelaksanaan pembinaan di Lembaga Pemasyaraktan lebih dioptimalkan melalui pembinaan yang terstruktur dan berkesinambungan agar Narapidana menyadari kesalahan dan tidak akan megulangi lagi pelanggaran yang telah dilakukan, serta mempunyai bekal keterampilan setelah Narapidana selesai menjalani masa pidananya.

\section{Faktorbudaya/kultural}

Kemudian juga dilakukan upayaupaya yang dapat mendukung pelaksanaan pemberian remisi tersebut yaitu, mengadakan hubungan kerjasama dan koordinasi yang baik dengan pihak-pihak terkait dengan Pengadilan Negeri, Pengadilan Tinggi, Kejaksaan Negeri, Kejasaan Tinggi, dan Kepolisian untuk dapat lebih cepat dalam pengiriman petikan vonis, eksekusi dari kejaksaan dan surat-surat penahanan dari Kepolisian sehingga dalam pengusulan remisi tidak menjadi suatu penghambat. Supaya narapidana itu dapat diusulkan sudah mendapatkan remisi khususnya 17 Agustus atau pada hari besar keagamaan.

\section{Penutup}

\section{A. Kesimpulan}

Berdasarkan uraian yang telah dikemukakan pada bab-bab terdahulu baik pada tinjauan kepada pustakaan maupun analisis data dan fakta yang ditemukan pada dalam penelitian, maka sampailah penulis pada bagian kesimpulan tesis ini yang pada pokoknya menyatakan sebagai berikut:

1. Menurut Undang-Undang Nomor 12 Tahun 1995 tentang Pemasyarakatan, pemberian remisi adalah hak narapidana. Implementasi pemberian remisi ternyata telah bergeser, disebabkan beberapa pengaturan menyangkut remisi yang menerapkan pasal-pasal karet yang bisa ditarik atau diulur (mulur mengkret) sesuai kepentingan pemberi dan penerima remisi. Akibatnya tolak ukur pemberian remisi menjadi kabur, samar-samar dan tidak jelas. Hal inilah yang membuka peluang terjadinya penyalahgunaan wewenang dan jabatan dalam pemberian remisi oleh pihak-pihak yang terkait dengan pemberian remisi tersebut kepada narapidana, sehingga pemberian remisi bukan lagi hak, bukan juga hadiah atau pemberian pemerintah, tetapi telah menjadi alat kepentingan.

2. Pengawasan pemberian remisi di Lembaga Pemasyarakatan melibatkan sebahagian komponen sistem peradilan pidana yaitu Pengadilan dan Lembaga 
Pemasyarakatan yang dilakukan mulai dari Unit Pelaksana Teknis Pemasyarakatan setempat yang mengusulkan perolehan remisi kepada Kantor

WilayahKementerianHukumdanHakAsa siManusiauntukditeruskankepada

Direktorat Jenderal Pemasyarakatan (Direktorat Bina Registrasi dan Statistik). Selanjutnya diterima oleh narapidana yang bersangkutan. Dalam melakukan tugas pengawasan itu juga melibatkan hakim pengawas dan pengamat yang menitikberatkan pengawasannya pada hak-hak Narapidana antara lain apakah Narapidana memperoleh hak-haknya sepanjang pemasyarakatanpemasyarakatan prosedural sesuai sistem pemasyarakatan telah dipenuhi termasuk pemberian asimilasi, remisi, cuti, lepas bersyarat/ integrasi dan lainlain.

3. Berkaitan dengan pemberian remisi masih terdapat hal-hal yang menghambat dalam pelaksanaannya yang menimbulkan akibat hukum bagi Narapidana, yaitu : Narapidana terlibat/ melakukan tindakan indisipliner sehingga hak untuk memperoleh remisi dicabut, hambatan lain adalah keterbatasan sumber daya manusia yang mencukupi dan memadai bagi kebutuhan pelaksanaan tugas pembinaan narapidana serta keterlambatan dalam hal persyaratan pengajuan remisi, karena selama ini pengerjaannya masih dilaksanakan secara manual. Disisi lain Adanya keterlambatan dalam hal persyaratan pengajuan remisi, serta keterlambatan petikan vonis dari Pengadilan dan eksekusi dari Kejaksaan serta Surat penahanan dari Kepolisian. Sehingga dilakukan berbagai upaya untuk mengatasi hambatan-hambatan tersebut melalui Melakukan pembinaan terstruktur dan berkesinambungan dengan tujuan supaya Narapidana menyadari kesalahannya dan tidak mengulangi pelanggaran lagi, meningkatkan sumber daya manusia petugas baik secara kualitas dan kuantitas dengan mengikutsertakan berbagai pelatihan terkait, mengadakan sarana penghitung Remisi melalui komputerisasi yang di program perhitungan Remisi, mengadakan sosialisasi kepada petugas khusus yang bertugas dibagian pembinaan (registrasi) dalam rangka meningkatkan pengetahuan tentang perhitungan dalam usulan remisi, mengadakan hubungan kerjasama yang baik dengan pihak-pihak terkait dengan Pengadilan, Kejaksaan dan Kepolisian untuk dapat lebih cepat dalam pengiriman petikan vonis, eksekusi dari kejaksaan dan surat-surat penahanan dariKepolisian.

\section{B. Saran}

Setelah melakukan pembahasan dan analisa terhadap permasalahan yang telah dikemukakan dalam tesis ini, maka sebagai saran yang dapat diberikan oleh penulis adalah:

1. Untuk mengatasi permasalahan Perundang-Undangan, Pemerintah harus konsisten dengan menginventarisir kembali seluruh peraturan yang terkait dengan Pemasyarakatan. Peraturan yang sudah tidak sesuai seharusnya segera ditinjau ulang dan diganti, sementara peraturanperaturan yang masih sesuai bahkan menjadi alat kebijakan kriminal yang berdampak baik dalam pelaksanaannya, supaya dilaksanakan dengan konsisten, tidak dilakukan pengeroposan dengan kebijakan baru yang justeru menimbulkan masalah serta menghilangkan nilai positif pada kebijakan yang lama.

Skep Menteri Kehakiman RI Nomor M.04.UM.01.06 tahun 1983 tentang Penetapan Lapas tertentu sebagai Rutan semestinya dicabut dan diganti dengan peraturan baru yang mewajibkan pemerintah untuk tidak mencampurkan Narapidana dengan Tahanan sesuai Undang-Undang Nomor 12 Tahun 1995. Terhadap Keputusan Menteri Kehakiman dan Hak Asasi Manusia RI Nomor : M.04.HN.02.01 tanggal 27 April 2001 dan Nomor M.01.HN.02.01 tanggal 22 Mei 2006, seyogyanya ditinjau ulang dan dicabut supaya tidak menimbulkan pasal-pasal karet yang membuka 
peluang penyalahgunaan wewenang dan jabatan dalam pemberian remisi dan hak-hak narapidana lainnya.

2. Untuk menghindari terjadinya kerancuan dalam melaksanakan pengawasan terhadap pelaksanaan pemberian remisi, disarankan supaya dibentuk suatu lembaga pengawas pemberian remisi tentu dengan suatu payung hukum yang kuat sebagai dasar bagi lembaga pengawas dalam melaksakan tugasnya. Dengan adanya suatu lembaga pengawas remisi dan payung hukumnya, diharapkan kurangnya koordinasi antar pengawas pemberian remisi tidak terjadi lagi atau dapat diminimalisir. Untuk mendukung hal tersebut perlu juga diadakan pertemuan rutin antara pengawas pemberian remisi yang dilakukan secara berkelanjutan.

3. Dalam rangka meminimalisir hambatanhambatan yang terjadi dalam rangka pelaksanaan pemberian remisi, disarankan untuk menjalin hubungan baik dan koordinasi dengan instansi terkait lainnya. Untuk mendukung pemberian remisi tersebut diperlukan sarana dan prasarana yang memadai berupa data base dalam penghitungan remisi serta peningkatan kompetensi Sumber Daya Manusia dengan mengadakan pelatihan yang berkesinambungan sesuai dengan kebutuhan.

\section{DAFTAR PUSTAKA}

\section{A. Buku-buku}

Mufham, A., 2006, Manajemen Pengawasan Refleksi \& Kesaksian Seorang Auditor, Ciputat; Kalam Indonesia.

Barda, A.N., \& Muladi, 1992, Teori-teori dan Kebijakan Pidana, Bandung ; Alumni.

, 1992, Lembaga Pidana Bersyarat, Bandung : Alumni.

2002, Hak Asasi Manusia, Politik dan Sistem Peradilan Pidana, Semarang : BP Universitas Diponegoro.

Prajudi, A., 1979, Administrasi Dan Manajemen Umum, Jakarta: Gunung Agung,
Romli, A., 1975, Dari Pemenjaraan Ke Pembinaan Narapidana, Bandung: Alumni, 1975. Disadur New Horizons In Criminology, Barnes Elmer Harry dan Teeters K. Negley. \& Soemadipradja, 1979, Sistem Pemasyarakatan di Indonesia, Bandung ; Bina Cipta.

Van, B., 1984, Hukum Pidana I, Bandung; Bina Cipta.

Soedjono, D., 1972, Dasar-Dasar Penologi Usaha Pembaharuan Sistem Kepenjaraan dan Pembinaan Narapidana, Bandung; Alumni Sejarah dan Azas-Azas Penologi (Pemasyarakatan), Bandung; Armico,1984.

Fauzan, M., 2006, Hukum Pemerintahan Daerah, Yogyakarta; PKHKD FH UNSOED dengan UII Press, 2006.

Gunakaya, A.W., 1988, Sejarah dan Konsep Pemasyarakatan, Bandung; Armico.

Harsono, CI.,1995, Sistem Baru Pembinaan Narapidana, Jakarta; Djambatan.

Andi, H., 1983 Suatu Tinjauan Ringkas Sistem Pemidanaan di Indonesia, Jakarta; Akademika Pressindo, 1983. 1985, Sistem Pidana dan Pemidanaan, Jakarta; Pradnya Paramita. , 2000, Kamus Hukum, Jakarta; Ghalia Indonesia, 2000.

Azhar, 1993, Pengukuran Efektivitas Dalam Organisasi, Jakarta ; Fakultas Ekonomi Universitas Indonesia.

Lembaga Administrasi Negara Republik Indonesia, Sistem Administrasi Negara Republik Indonesia Jilid II/Edisi Ketiga, Jakarta ; Toko Gunung Agung, 1997.

1997, Sistem Administrasi Negara RI, Jakarta: Gunung Agung. 2007, Sistem Administrasi Negara RI, Jakarta: Gunung Agung.

Lamitang, P.A.F., 1984, Hukum Penitensier di Indonesia, Bandung ; Armico.

Lotulung E.P., 1986, Beberapa Sistem Tentang Kontrol Segi Hukum Terhadap Pemerintah, Jakarta ; Bhuana Pancakarsa

Marpaung, L, 2005, Asas Teori Praktik Hukum Pidana, Jakarta ; Sinar Grafika. 
Moeljatno, 1983, Asas-Asas Hukum Pidana, Jakarta ; Bina Aksara.

Panjaitan, I.P. dan Simorangkir P., 1995, Lembaga Pemasyarakatan Dalam Perspektif Sistem Peradilan Pidana, Jakarta; Pustaka Sinar Harapan.

Dwidja, P. 2006, Sistem Pelaksanaan Pidana Penjara di Indonesia, Bandung; Refika Aditama,

Bambang, P, 1982, Hukum Pidana Kumpulan Karangan Ilmiah, Jakarta ; Aksara,. , Pelaksanaan Pidana Penjara dengan SistemPemasyarakatan, Yogyakarta ; Liberty,1986.

Reksodiputro Mardjono, Kriminologi dan Sistem Peradilan Pidana, Jakarta ; Pusat Pelayanan Keadilan dan Pengadian Hukum Universitas Indonesia, 1997.

Rukmini Mien, Perlindungan HAM Melalui Asas Praduga Tidak Bersalah dan Asas Persamaan Kedudukan Dalam Hukum Pada Sistem Peradilan Pidana di Indonesia, Bandung ; Alumni, 2003.

Aspek Hukum Pidana dan Kriminologi, Bandung ; Alumni,2006.

Samosir Djisman, Fungsi Pidana Penjara Dalam Sistem Pembinaan di Indonesia, Bandung ; Bina Cipta, 1992.

Siagian P. Sondang, Filsafat Administrasi, Jakarta ; Bumi Aksara, 2004.

Sianturi SR, Asas-Asas Hukum Pidana di Indonesia dan Penerapannya, Jakarta ; Alumni AHAEM PETEHAEM, 2002.

Sholehuddin, Sistem Sanksi Dalam Hukum Pidana Ide Dasar Double Track System dan Implementasinya, Jakarta ; PT Raja Grafindo Persada, 2003.

Soekanto Soerjono \& Mamudji Sri, Penegakan Hukum Normatif Suatu Tinjauan Singkat, Jakarta ; Raja Grafindo Persada, 2003.

Soemadi, R. Achmad S. Pradja dkk, Sistem Pemasyarakatan di Indonesia, Bandung: Binacipta, 1979

Sujatno Adi, Sistem Pemasyarakatan Indonesia (Membangun Manusia
Mandiri), Jakarta ; Direktorat Jenderal Pemasyarakatan, 2004.

Sudirman Didin, Masalah-masalah Aktual Bidang Pemasyarakatan, Jakarta ; Pusat Pengkajian dan Pengembangan Kebijakan Departemen Hukum dan Hak Asasi Manusia RI, 2006.

Susanto F. Anthon, Wajah Peradilan Kita Konstruksi Sosial Tentang Penyimpangan, Mekanisme Kontrol dan Akuntabilitas Peradilan Pidana, Bandung ; Refika Aditama, 2004.

Sumitro Hanitijo Ronny, Metodologi Penelitian Hukum dan Yumetri, Jakarta ; Ghalia Indonesia, 1994.

Sunarso Siswanto, Wawasan Penegakan Hukum di Indonesia, Bandung ; Citra Aditya Bakti, 2005.

Sudarto, Kapita Selekta Hukum Pidana, Bandung ; Alumni, 1986.

Suwandi, Instrumen Penegakan HAM di Indonesia, Bandung ; Refika Aditama, 2004.

Syaputra, M.Y.A., (2011), Penafsiran Hukum oleh Hakim Mahkamah Konstitusi, Mercatoria, 4 (2): 85-98

Tjandra Riawan W., Hukum Keuangan Negara, (Jakarta ; Grasindo, 2006).

Perundang-undangan

Himpunan Peraturan Perundang-undangan tentang Pemasyarakatan Bidang Pembinaan Direktorat Jenderal Pemasyarakatan.

Kitab Undang-undang Hukum Acara Pidana.

Keputusan Presiden Nomor 174 Tahun 1999 tentang Remisi.

Peraturan Pemerintah Nomor 31 Tahun 1999 tentang Pembinaan Warga Binaan Pemasyarakatan.

Peraturan Pemerintah Nomor 32 Tahun 1999 tentang Syarat dan Tata Cara Pelaksanaan Pembinaan dan Pembimbingan Warga Binaan Pemasyarakatan.

Peraturan Pemerintah Nomor 12 Tahun 1995 tentang Pemasyarakatan.

Instruksi Presiden Nomor 15 Tahun 1983 tentang Pedoman Pelaksanaan Pengawasan.

Makalah danSeminar

Direktorat Jenderal Pemasyarakatan Departemen Kehakiman dan Hak 
Asasi ManusiaRI.,“40

TahunPemasyarakatan Mengukir

Citra Profesionalisme", Makalah, Jakarta Tahun 2004.

Ma'mun, "Revitalisasi dan Fungsi Lapas"

Makalah disampaikan dalam

seminar tentang : Revitalisasi

Fungsi dan Peran Lembaga

Pemasyarakatan. Program Pasca

Sarjana Program Studi Pengkajian

Ketahanan Nasional Kekhususan

Kajian Strategis Kebijakan

Manajemen. Jakarta: Universitas

Indonesia, tanggal 25 Nopember 2006.

Reksodiputro, M., 1990, "Hak Tersangka dan Terdakwa Dalam KUHAP Sebagai Bagian Dari Hak-hak Warga Negara (Civil Rights)".Makalah disampaikan pada Seminar Tentang KUHAP, Jakarta: Fakultas Hukum Indonesia.

Resodiputro, M., 1990, “Tugas Hakim Pengawas dan Pengamat Dalam Pembinaan Narapidana dan Terpidana di Dalam dan Luar Lembaga Pemasyarakatan". Makalah disampaikan pada Seminar Nasional Pemasyarakatan Terpidana II, Universitas Indonesia.

Purwoto S.G., 1991, "Peran dan Tanggung Jawab Hakim Pengawas dan Hakim Pengamat Terhadap Putusan Pidana yang dijatuhkan", Makalah, disampaikan pada Seminar Nasional Hukum Pidana, Jakarta, Fakultas Hukum Universitas Indonesia, Tahun 1991.

Soerjobroto, B., 1971, "Pelaksanaan Sistem Pemasyarakatan", Makalah, disampaikan pada Workshop Pemasyarakatan di Jakarta tahun 1971.

Syahbarani, H., dan Saparudin, (2009), Kebebasan Lembaga Pengadilan Dalam Sistem Hukum Indonesia, Mercatoria, 2 (2): 78 - 89 